\title{
Occurrence and distribution of Gigaspora under Cryptostegia madagascariensis Bojer Ex Decne in Brazilian tropical seasonal dry forest ${ }^{1}$
}

\author{
Edjane Oliveira de Lucena ${ }^{2}$, Tancredo Augusto Feitosa de Souza ${ }^{3}$, Jackson da Silva Araújo ${ }^{4}$, \\ Leonaldo Alves de Andrade ${ }^{5}$, Djail Santos ${ }^{6}$, Guilherme Silva de Podestá ${ }^{7}$
}

\begin{abstract}
The Brazilian tropical seasonal dry forest presents high abundance of arbuscular mycorrhizal fungal from Order Diversisporales, but the occurrence and distribution of Gigaspora species (Order Diversisporales) in invaded zones by exotic plant species in the Caatinga are not know yet. Here, we compare the occurrence and distribution of Gigaspora community in soils from invaded zone by the exotic plant species $C$. madagascariensis and soils from native zone by the native plant species M. tenuiflora from Brazilian tropical seasonal dry forest, Pombal, Paraiba, Brazil. We analysed and compared the number of spores and frequency of occurrence of Gigaspora species using $40 \mathrm{~m}$ transects and morphological analyses. In general, the most dominant Gigaspora species in the invaded zone was Gigaspora albida, whereas we did not find any dominance by Gigaspora species in the native zone. Differences in Gigaspora occurrence and distribution were associated with (1) the dominant plant species (C. madagascariensis vs. M. tenuiflora) that alter the occurrence and frequency of Gigaspora in field conditions from the Brazilian semiarid region, (2) the transition zone, where G. albida and G. margarita did not occur, and (3) specific plant-AMF pairing, where we identified G. gigantea as the most resilient AMF species occurring in all the studied sections into the $40 \mathrm{~m}$ transects. These results contribute to a deeper view about the Gigaspora occurrence and distribution in invaded and native zones of the Brazilian semiarid and open new perspective for ecological studies addressing specific AMF taxa and other exotic plant species in the Brazilian tropical seasonal dry forest.
\end{abstract}

Keywords: Brazilian semiarid; Gigaspora albida; Gigaspora gigantea; Gigaspora margarita; arbuscular mycorrhizal fungi.

\section{Ocorrência e distribuição do gênero Gigaspora em Cryptostegia madagascariensis Bojer Ex Decne na Caatinga}

\begin{abstract}
Resumo: A região semiárida brasileira apresenta elevada abundância de micorrizas da ordem Diversisporales, contudo a ocorrência e a distribuição de espécies de fungos micorrízicos do gênero Gigaspora (Ordem Diversisporales) em áreas em processo de invasão biológica dentro da Caatinga ainda é desconhecida. Avaliou-se a ocorrência e a distribuição de espécies do gênero Gigaspora em solos de ambientes invadidos pela espécie de planta exótica C. madagascariensis e solos de ambiente nativos pela espécie de planta nativa $M$. tenuiflora. da Caatinga brasileira, Pombal, Paraíba, Brasil. Foram analisados e comparados o número de esporos e a frequencia de ocorrência de espécies do gênero Gigaspora usando transectos de $40 \mathrm{~m}$ e análises morfológicas do esporos.A comunidade de Gigaspora nas zonas invadidas e nativas foram dissimilares. Em geral, a espécie de Gigaspora observada como dominante na zona invadida foi Gigaspora albida, enquanto que não foi verificado dominância das espécies de Gigaspora na zona nativa. Diferenças na ocorrência e distribuição do gênero Gigaspora foram associadas com (1) o tipo de espécie de planta dominante (C. madagascariensis vs. M. tenuiflora) que alteraram a ocorrência e frequência de espécies do gênero Gigaspora em condições de campo do semiárido brasileiro, (2) a zona de transição, onde não foi observada ocorrência das espécies G. albida e G. margarita, e (3) pareamento planta-fungo específico, onde constatouse a espécie $G$. gigantea como a mais resiliente espécie de fungo micorrízicos observada em todas as seções estudadas dentro do transecto de $40 \mathrm{~m}$. Estes resultados contribuem com uma visão mais aprofundada sobre a distribuição e ocorrência de espécies do gênero Gigaspora em zonas invadidas e nativas do semiárido brasileiro e abrem novas perspectivas para estudos ecológicos referentes a grupos específicos de FMA e outras espécies de plantas exóticas da Caatinga brasileira.
\end{abstract}

Palavras-chave: Fungos micorrízicos arbusculares; Gigaspora albida; Gigaspora gigantea; Gigaspora margarita; Semiárido brasileiro.

\footnotetext{
${ }^{1}$ Submetido em 29/05/2018 e a provado em 04/02/2019

${ }^{2}$ Mestre em Ciências Florestais; Doutoranda, Universidade Federal da Paraíba (UFPB), Centro de Ciências Agrárias, Programa de PósGraduação em Ciência do Solo, Areia-PB, CEP: 58397-000; E-mail: edjanelucenaengflo@gmail.com

${ }^{3}$ Doutor em Ciência do Solo; Bolsista PNPD/CAPES, Universidade Federal da Paraíba (UFPB), Centro de Ciências Agrárias, Programa de Pós-Graduação em Ciência do Solo, Areia-PB, CEP: 58397-000; E-mail: tancredo_agro@hotmail.com

${ }^{4}$ Graduando em Agronomia; Bolsista PIBIC/CNpq, Universidade Federal da Paraíba (UFPB), Centro de Ciências Agrárias, Areia-PB, CEP: 58397-000; E-mail: jackon.arj40@gmail.com

${ }^{5}$ Doutor em Ciência Florestal; Professor Titular, Universidade Federal da Paraíba (UFPB), Centro de Ciências Agrárias, Areia-PB, CEP: 58397000; E-mail: professorleonaldo@gmail.com

${ }^{6}$ Doutor em "Crop and Soil Science"; Professor Titular, Universidade Federal da Paraíba (UFPB), Centro de Ciências Agrárias, Areia-PB, CEP: 58397-000; E-mail: santos.djail@gmail.com

${ }^{7}$ Doutor em Agronomia; Professor, Universidade Federal da Paraíba (UFPB), Centro de Ciências Agrárias, Areia-PB, CEP: 58397-000; Email: guilherme@cca.ufpb.br
} 


\section{Introduction}

The Brazilian semiarid region is characterized by high diversity and variability of arbuscular mycorrhizal fungi (AMF) (Souza and Freitas, 2017; Schußler et al., 2001). According to Silva et al. (2014) during the dry season the frequency of occurrence of different AMF species in the Brazilian semiarid increase through high fungal sporulation. Goto et al. (2012) and Marinho et al. (2014) describe the Brazilian semiarid as a diversification and dispersion centre of species from Diversisporales. Nowadays, Diversisporales encompassed nine genus, within them genus Gigaspora (Souza, 2015) and there are many works showing the occurrence and distribution of Gigaspora around the world (Goto et al., 2012; Souza, 2015; Souza and Santos, 2018), however, the occurrence and distribution of this genus on invaded environments of Brazilian semiarid remain unclear.

In this context, our work addressed the following question: Could Cryptostegia madagascariensis Bojer ex. Decne., an invasive plant species from tropical seasonal dry forest, alters the occurrence and distribution of Gigaspora species into invaded areas of Brazilian semiarid? According to Souza et al. (2015) this invasive plant species can reduce AMF diversity and alter AMF community composition of sandy soils. Oehl et al. (2011) reported that some AMF species respond specifically to the intensity of land use and plant diversity, which suggests that genus Gigaspora occurrence also can be altered by $C$. madagascariensis presence.

Many studies have showed that AMF species from genus Gigaspora occur with high frequency in natural ecosystems from Brazilian semiarid (i.e., Mimosa tenuiflora (Willd.) Poir, Licania rigida Benth., Copernicia prunifera (Miller) H. E. Moore and Ziziphus joazeiro Mart.), whereas in invaded ecosystems by exotic plant species this AMF genus occur with low frequency or it can be absent from the changed-AMF community by biological invasion (Goto et al., 2012; Marinho et al. 2014; Souza et al., 2015; Souza et al., 2016a; Souza et al., 2018; Souza e Freitas, 2017; Souza e Santos, 2018).

Our aim here was to investigate how $C$. madagascariensis alters the occurrence and distribution of Gigaspora species in a natural ecosystem on a Regosol occupied by $M$. tenuiflora (native plant species) and $C$. madagascariensis (invasive plant species).

\section{Material and Methods}

We selected study environments near Pombal,

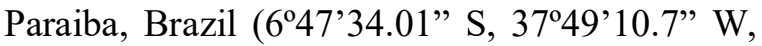
and average altitude $183 \mathrm{~m})$. The climatic condition of the studied environments is Bsh (Köppen), hot semi-arid, temperature of $28^{\circ} \mathrm{C}$ and annual precipitation scanty and irregular of $963.07 \mathrm{~mm}$ (Souza et al., 2016a). The soil type was classified as an Eutric Cambisol with low contents of total organic carbon $\left(8.61 \mathrm{~g} \mathrm{~kg}^{-1}\right)$ and available P (2.31 $\mathrm{mg} \mathrm{dm}^{-3}$ ) (WRB, 2006).

The exotic Cryptostegia madagascariensis Bojer ex. Decne. and the native Mimosa tenuiflora (Willd.) Poir, which co-occur into the riparian forest in the Brazilian tropical seasonal dry forest from Paraiba, Brazil were selected. Both plant species were selected according to the following criteria: (1) the plant had a diameter near soil surface $>3 \mathrm{~cm}$; (2) the plant had a height higher than $2 \mathrm{~m}$; (3) in flowering stage; and (4) no individual from a different plant species were growing in a 3-m radius to the selected plant in all directions (Souza et al., 2018).

We collected samples containing soil and root fragments at $0.10 \mathrm{~m}$ depth, using $40 \mathrm{~m}$ transects $(n=10)$ in eight different position between an invaded and a native zone. So, the transect was divided into 5 meters sections and then four soil samples were collected within each 5 meters section: $\mathrm{EXO}_{\mathrm{DL}}$ - Under the drip line of $C$. madagascariensis (exotic plant species) and located $20 \mathrm{~m}$ from the transition zone; $\mathrm{EXO}_{15}-$ Within the invaded zone and located $15 \mathrm{~m}$ from the transition zone; $\mathrm{EXO}_{10}-$ Within the invaded zone and located $10 \mathrm{~m}$ from the transition zone; $\mathrm{EXO}_{5}-$ Within the invaded zone and located $5 \mathrm{~m}$ from the transition zone; $\mathrm{NAT}_{5}-$ Within the native zone and located $5 \mathrm{~m}$ from the transition zone; $\mathrm{NAT}_{10}$ - Within the native zone and located $10 \mathrm{~m}$ from the transition zone; $\mathrm{NAT}_{15}$ - Within the native zone and located $15 \mathrm{~m}$ from the transition zone; and $\mathrm{NAT}_{\mathrm{DL}}$ - Under the drip line of $M$. tenuiflora (native plant species) and located $20 \mathrm{~m}$ from the transition zone (Fig. 1).

Spores of Gigaspora species extracted from native and invaded zone were classified as "Changed-Gigaspora community" if they occurred in the invaded zone only, and as "unaltered-Gigaspora community" if they

Revista Agropecuária Técnica, Areia-PB, v. 39, n. 3, p. 221-227, 2018

DOI: 10.25066/agrotec.v39i3.40055 
occurred in the native zone only (Souza et al., 2018). Spores from field were extracted by the wet sieving technique (Gerdemann and Nicolson, 1963), followed by sucrose centrifugation (Jenkins, 1964). For this, we used $100 \mathrm{~g}$ of field soil. Initially, the extracted spores were examined in water under a dissecting microscope and they were separated based on morphology. After it, they were mounted in polyvinyl alcohol lactoglycerol (PVLG) with or without addition of Melzer's reagent (Walker et al., 2007). The identification of Gigaspora species was based on the description provided by consulting the LBM website

(http://glomeromycota.wixsite.com/lbmicorrizas/ chaves-de-identificao). In this work we adopted the classification proposed by Oehl et al. (2011). We assessed spore abundance (total number of spores of each Gigaspora species recorded), and the species occurrence frequency $\left(F O_{i}\right)$ of each Gigaspora species. $F O_{i}$ was calculated using the following equation: $F O_{i}=\mathrm{n}_{\mathrm{i}} / \mathrm{N}$, where $\mathrm{n}_{\mathrm{i}}$ is the number of times a Gigaspora species was observed and $\mathrm{N}$ is the total of Gigaspora spores observed from each studied section into the transects.

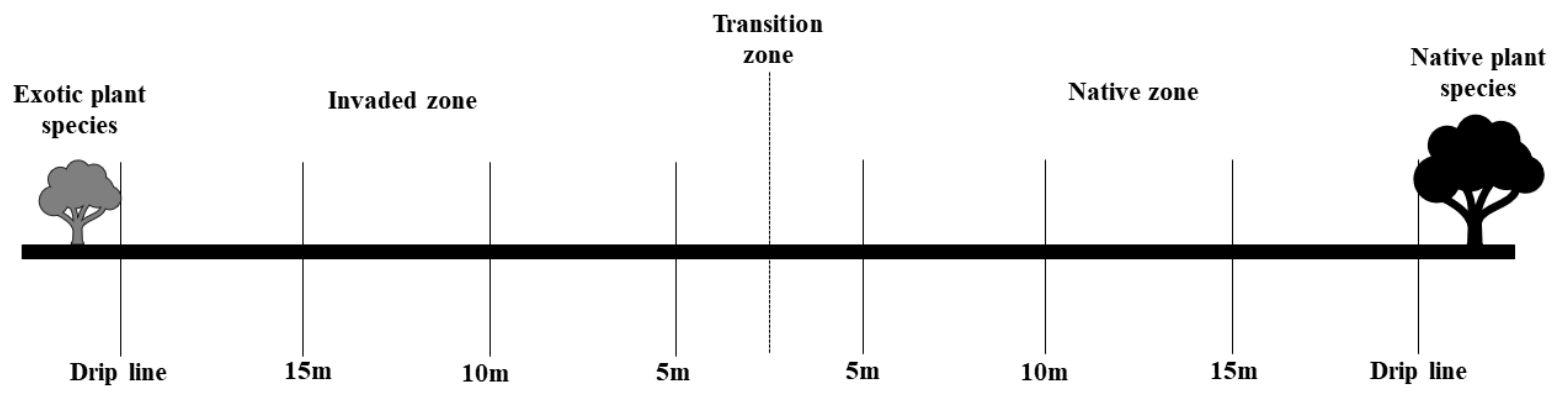

Figure 1 Sampling methodology scheme of soil samples along a transect between native and invaded zone.

The Kolmogorov-Smirnov test was applied to assess the normality of the data distribution. Student $t$ test for independent samples was carried out to investigate differences between native and invaded zone in spore abundance of Gigaspora species. Two-way ANOVA was used to test for the effect of biological invasion by $C$. madagascariensis on occurrence and distribution of Gigaspora species. Data sets were arcsin $\log _{n}$ transformed. Notwithstanding, the results are presented in their original scale of measurement (mean \pm standard deviation). Multiple comparisons of means were performed by the Bonferroni test $(P<0.05)$ after performing twoway ANOVA. The $t$ test, two-way ANOVA, and Bonferroni's multiple comparison testes were conducted using the stats package of the $\mathrm{R}$ statistical program.

\section{Results}

In total, we identified 3 different Gigaspora species corresponding to: Gigaspora albida N.C. Shenck \& G.S. Sm., Gigaspora gigantea (T.H. Nicolson \& Gerd.) Gerd. \& Trappe, and Gigaspora margarita Becker \& Hall. Significant differences between native (NAT) and invaded (EXO) zone were found for Gigaspora total abundance and Gigaspora species in all studied zones. Across the investigated sections into the transects, the invaded zone had a Gigaspora total abundance ranging from $1.1 \pm 0.3$ to $28.2 \pm 0.4$ spores/100g soil, whereas in the native zone the Gigaspora total abundance ranged from $5.8 \pm 0.4$ to $45.0 \pm 0.3$ spores $/ 100 \mathrm{~g}$ soil. The number of spores of $G$. albida $(P<0.05), G$. gigantea $(P<$ $0.05)$ and $G$. margarita $(P<0.05)$ were significantly higher in the native zone. However, no differences between invaded and native zone were obtained for G. albida into the $\mathrm{EXO}_{5}$ and $\mathrm{NAT}_{5}$ sections $(P<0.5698)$; and $G$. gigantea into the $\mathrm{EXO}_{10}$ and $\mathrm{NAT}_{10}(P<0.7366)$ and $\mathrm{EXO}_{5}$ and $\mathrm{NAT}_{5}(P<0.6598)$ sections. Not only G. albida abundance was particularly high in the native zone, but also $G$. gigantea and $G$. margarita abundance (Table 1).

The most abundant taxa in the invaded zone were $G$. gigantea (63.68 \%), whereas $G$. margarita $(38.13 \%)$ were mostly found in the native zone. We also observed that G. albida and $G$. gigantea were both the most frequent and dominant Gigaspora species in the $\mathrm{EXO}_{\mathrm{DL}}$ and $\mathrm{NAT}_{\mathrm{DL}}$ sections, respectively. But, these conditions changed near the transition zone, where G. gigantea was the only one Gigaspora

Revista Agropecuária Técnica, Areia-PB, v. 39, n. 3, p. 221-227, 2018

DOI: 10.25066/agrotec.v39i3.40055 
species observed in both $\mathrm{EXO}_{5}$ and $\mathrm{NAT}_{5}$ field soil samples. We did not find any G. albida species in the $\mathrm{EXO}_{10}$, and for the $\mathrm{EXO}_{5}$, we did not observe both G. albida and G. margarita species (Figure 2).

Table 1 Number of spores of Gigaspora species (mean $\pm \mathrm{SD}, N=320$ ) from the four studied section into the transects between invaded and native zone

\begin{tabular}{ccccc}
\hline $\begin{array}{c}\text { Studied } \\
\text { zones }\end{array}$ & $\begin{array}{c}\text { Gigaspora total } \\
\text { abundance }\end{array}$ & G. albida. & G. gigantea & G. margarita \\
\hline EXO $_{\mathrm{DL}}$ & $8.1 \pm 0.1 \mathrm{~d}$ & $4.1 \pm 0.5 \mathrm{~d}$ & $3.0 \pm 0.1 \mathrm{~d}$ & $1.0 \pm 0.1 \mathrm{e}$ \\
NAT $_{\mathrm{DL}}$ & $45.6 \pm 0.3^{* \mathrm{a}} \mathrm{a}$ & $12.2 \pm 0.3^{*} \mathrm{~b}$ & $17.2 \pm 0.3^{*} \mathrm{a}$ & $16.2 \pm 0.1^{*} \mathrm{a}$ \\
\hline EXO $_{15}$ & $17.5 \pm 0.4^{*} \mathrm{c}$ & $6.2 \pm 0.7 \mathrm{c}$ & $8.1 \pm 0.2 \mathrm{c}$ & $3.2 \pm 0.2 \mathrm{~d}$ \\
NAT $_{15}$ & $40.0 \pm 0.2 \mathrm{~b}$ & $17.1 \pm 0.5^{*} \mathrm{a}$ & $11.0 \pm 0.1^{*} \mathrm{~b}$ & $11.9 \pm 0.6^{*} \mathrm{~b}$ \\
\hline EXO10 $_{10}$ & $4.2 \pm 0.1 \mathrm{e}$ & $0.0 \pm 0.0 \mathrm{f}$ & $3.0 \pm 0.5 \mathrm{~d}$ & $1.2 \pm 0.3 \mathrm{e}$ \\
NAT $_{10}$ & $17.5 \pm 0.2^{*} \mathrm{c}$ & $5.1 \pm 0.3^{*} \mathrm{c}$ & $4.0 \pm 0.6^{\text {ns }} \mathrm{d}$ & $8.1 \pm 0.1^{*} \mathrm{c}$ \\
\hline EXO $_{5}$ & $1.0 \pm 0.3 \mathrm{f}$ & $0.0 \pm 0.0 \mathrm{f}$ & $1.0 \pm 0.6 \mathrm{e}$ & $0.0 \pm 0.0 \mathrm{f}$ \\
NAT $_{5}$ & $5.1 \pm 0.4^{*} \mathrm{e}$ & $1.0 \pm 0.1^{\text {ns }} \mathrm{e}$ & $2.1 \pm 0.5^{\mathrm{ns}} \mathrm{e}$ & $2.0 \pm 0.1^{*} \mathrm{e}$ \\
\hline
\end{tabular}

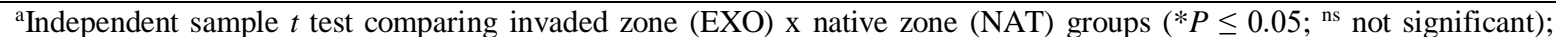
Different letters indicate significant differences among the studied zones assessed by the Bonferroni test $(P<0.05)$ after performing two-way ANOVA.

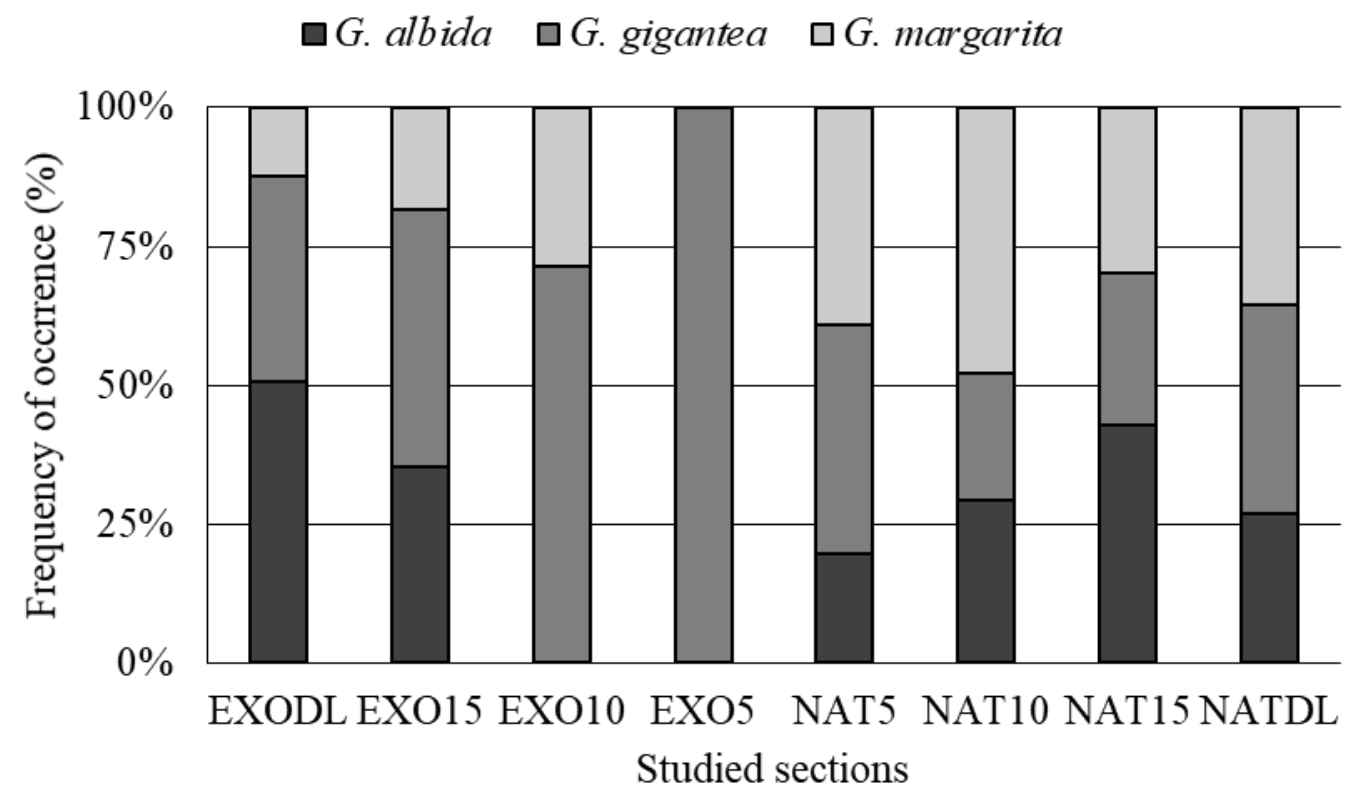

Figure 2 Frequency of occurrence $\left(\mathrm{FO}_{\mathrm{i}}\right)$ of Gigaspora species of each studied section into the $40 \mathrm{~m}$ transect $(N=$ 320) between invaded and native zone. $\mathrm{FO}_{\mathrm{i}}=\mathrm{n}_{\mathrm{i}} / \mathrm{N}$, where $\mathrm{n}_{\mathrm{i}}$ is the number of times an AMF species was observe and $\mathrm{N}$ is the total of AMF spores observed from each studied condition.

\section{Discussion}

Our results provided evidence for changes in the occurrence and distribution of Gigaspora species caused by $C$. madagascariensis presence. In fact, biological invasion by $C$. madagascariensis may influence negatively AMF community by changing soil properties and native plants community composition as described by Souza et al. (2016a). These results support our main hypothesis that $C$. madagascariensis, an invasive plant species from Brazilian tropical seasonal dry forest may negatively alters the occurrence and distribution of Gigaspora by changing total abundance of gigasporoid spores and frequency of occurrence of Gigaspora species between the invaded and native zone. It is not usual to report Gigaspora community composition in invaded zones of the Brazilian semiarid (Souza et al., 2016a; Souza and Freitas 2017; Souza et al., 2018), but results 
here showed that Gigaspora is a very common AMF species under natural ecosystem of Brazilian semiarid (Mello et al., 2012; Pereira et al., 2014; Silva et al., 2014; Souza et al., 2016b).

We also observed differences in the Gigaspora community composition between invaded and native zone. In fact, invasive plants species may influence arbuscular mycorrhizal fungi community composition in different ways (Zubek et al., 2016). In the transect sections, we observed that: i) G. albida was the Gigaspora species that presented most affinity with $C$. madagascariensis; ii) G. gigantea was the most resilient Gigaspora species, once we had find their spores in all studied sections; iii) Even the most frequent Gigaspora species being $G$. gigantea in the native zone, we did not observed any dominance by the three identified Gigaspora species in this field study; and iv) in transition zone between invaded and native plant communities, both G. albida and $G$. margarita were negatively affected by the reduction of native plants diversity. These results are in agreement with previous studies (Callaway et al., 2008; Mummey and Rillig, 2006; Vogelsang and Bever, 2009) and support the hypothesis proposed by Hausmann and Hawkes (2009) that plant neighbours are very important in structuring AMF communities and the presence of invasive plants changes AMF composition in roots of their native neighbours (Hawkes et al., 2006). Bini et al. (2018) reported that the number of Gigaspora spores and the frequency of occurrence of arbuscular mycorrhizal fungal species decreased 100.0 and $56.7 \%$, respectively because intercropping two exotic plant species, Eucalyptus grandis and Acacia mangium in a Rhodic Ferralsol, Brazil. Examining other studies around the world, we found negative effects of Stevia rebaudiana Bertoni on Gigaspora occurrence (Astuti et al., 2018) and a significant reduction (on average51.3\%) on Gigaspora frequency of occurrence as a result of initial exotic plant seeding mixture (Henning et al., 2018) in Indonesia and U.S.A., respectively.

The modification of occurrence and frequency of Gigaspora species suggests a functional adaptation of the arbuscular mycorrhizal fungal species to the soil conditions and to the physiological requirement of their host trees (e.g. $C$. madagascariensis in the invaded zone; and $M$. tenuiflora in the native zone) for the Gigaspora species (Courty et al., 2018). Souza et al. (2016a, b) demonstrated that the arbuscular mycorrhizal fungal communities were highly influenced by biological invasion and plant community diversity. According to Martinez-García et al. (2015) fungal alpha diversity decreased and beta diversity increased with undisturbed ecosystem age. In our study, we observed a reduction of the abundance of Gigaspora species from the native zone to the invaded zone. Interestingly, the same trend of reduction of the abundance of arbuscular mycorrhizal community has been reported in other studies (Zhang et al., 2010; Zubek et al., 2016; Erktan et al., 2018).

\section{Conclusion}

The main findings of this study may be summarized as follows: (1) invasive plant species as $C$. madagascariensis alter the occurrence and frequency of Gigaspora in field conditions from the Brazilian semiarid region, (2) G. albida and G. margarita did not occur in the transition zone between the invaded and native zone, and (3) among the three identified species from Gigaspora, G. gigantea was the most resilient AMF species occurring in all the studied sections into the $40 \mathrm{~m}$ transects. Our findings suggest that the biological invasion by $C$. madagascariensis can alter the composition of the Gigaspora community, an important taxon from the Order Diversisporales in the Brazilian semiarid region. Despite our results are an important contribution to our understanding on the importance of considering the impacts of biological invasion by exotic plant species on specific taxa of AMF species.

\section{Acknowledgement}

The authors gratefully acknowledge the support, generosity, use of services and facilities of the "Programa de Pós-Graduação em Ciência do Solo" and "Grupo de pesquisa Tenda" without which the present study could not have been completed. Also, this study was financed in part by CAPES and CNPq - Brasil.

\section{References}

Astuti, D. Y.; Parjanto; Cahyani, V. R. Mycorrrhizal diversity of stevia (Stevia rebaudiana Bertoni) rhizosphere in Tawangmangu, Indonesia. IOP Conf. Series: 
Earth and Environmental Sciences, v.129, 2018. https://doi.org/10.1088/1755-1315/129/1/012007

Bini, D.; Santos, C. A.; Silva, M. C. P.; Bonfim, J. A.; Cardoso, E. J. B. N. Intercropping Acacia mangium stimulates AMF colonization and soil phosphatase activity in Eucalyptus grandis. Scientia Agricola, v.75, n.2, p.102-110, 2018. http://dx.doi.org/10.1590/1678-992X-2016-0337

Callaway, R.M.; Cipolini, D.; Barto, K.; Thelen, G.C.; Hallett, S.G.; Prati, D.; Stinson, K.; Klironomos, J. Novel weapons: invasive plant suppresses fungal mutualists in American but not in its native Europe. Ecology, v.89, n.4, p. 1043-1055, 2008. https://doi.org/10.1890/07-0370.1

Courty, P.E.; Buée, B.; Tech, J. J. T.; Brulé, D.; Colin, Y.; Leveau, J.H.J.; Uroz, S. Impact of soil pedogenesis on the diversity and composition of fungal communities across the California soil chronosequence of Mendocino. Mycorrhiza, v. $28, \quad$ n.4 p.343-356, 2018. https://doi.org./10.1007/s00572-018-0829-9

Erktan, A.; McCormack, M. L.; Roumet, C. Frontiers in root ecology: recent advances and future challenges. Plant Soils. v.424, n.1-2, p.19, 2018. https://doi.org/10.1007/s11104-018-3618-5

Gerdemann, J. W.; Nicolson, T. H. Spores of mycorrhizal Endogone species extracted from soil by sieving and decanting. Transactions of the British Mycological Society, v.46, n.2, p.235-244, 1963. https://doi.org/10.1016/S00071536(63)80079-0

Goto, B.T.; Silva, G.A.; Assis, D.M.A.; et al. Intraornatosporaceae (Gigasporales), a new family with two new genera and two new species. Mycotaxon, v.119, n.16, p.117-132, 2012. https://dx.doi.org/10.5248/119.117

Hausmann, N.T.; Hawkes, C.V. Plant neighborhood control of arbuscular mycorrhizal community composition. New Phytologist, v.183, p.1188-1200, 2009. https://dx.doi.org/10.1111/j.1469-8137.2009.02882.x

Hawkes, C.V.; Belnap, J.; D'Antonio, C.; Firestone, M.K. Arbuscular mycorrhizal assemblages in native plant roots change in the presence of invasive exotic grasses. Plant and Soil, v.281, n.1-2, p.369-380, 2006. https://doi.org/10.1007/s11104-005-4826-3

Henning, J. A.; Weiher, E.; Lee, T. D.; Freund, D.; Stefanski, A.; Bentivenga, S. P. Mycorrhizal fungal spore community structure in a manipulated prairie. Restoration Ecology, v.26, n.1, p.124-133, 2018. https://dx.doi.org/10.111/rec.12548

Jenkins, W. R. A rapid centrifugal flotation technique for separation nemathodes from soil. Plant Disease Reporter, v.48, p.692, 1964. https://www.cabdirect.org/cabdirect/abstract/1965080110 $\underline{5}$

Marinho, F.; Silva G.A.; Ferreira, A.C.A.; Veras, J. S. da N.; Sousa, N. M. F. de; Goto, B.T.; Oehl, F. Bulbospora minima, a new species in the Gigasporales from semi-arid Northeast Brazil. Sydowia. v.66, p.313-323, 2014. https://dx.doi.org/10.12905/0380.sydowia66(2)2014-0313

Martínez-García, L.B.; Richardson, S.J.; Tylianakis, J.M.; Peltzer, D.A.; Dickie, I.A. Host identity is a dominant driver of mycorrhizal fungal community composition during ecosystem development. New Phytologist, v.205, n.4, p.1565-1576, 2015. https://doi.org/10.1111/nph.13226

Mello, C.M.A.; Silva, I.R.; Pontes, J.S.; et al. Diversidade de fungos micorrízicos arbusculares em área de Caatinga, PE, Brazil. Acta Botanica Brasilica. v.26, n.4, p.938-943, $2012 . \quad$ http://dx.doi.org/10.1590/S0102$\underline{33062012000400023}$

Mummey, D.L.; Rillig, M.C. The invasive plant species Centaurea maculosa alters arbuscular mycorrhizal fungal communities in the field. Plant and Soil, v.288, n.1-2, p.81-90, 2006. https://doi.org/10.1007/s11104-006-9091-6

Oehl, F.; Sieverding, E.; Palenzuela, J.; Ineichen, K.; Silva, G.A. Advances in Glomeromycota taxonomy and classification. IMA Fungus, v.2, p.191-199, https://dx.doi.org/10.5598/imafungus.2011.02.02.10

Pereira, C.M.R.; Silva, D.K.A.; Ferreira, A.C.A.; Goto, B.T.; Maia, L.C. Diversity of arbuscular mycorrhizal fungi in Atlantic forest areas under different land uses. Agriculture, Ecosystems and Environment, v.185, n.1, p.245-252, 2014. https://doi.org/10.1016/j.agee.2014.01.005

Silva, I.R.S.; Mello, C.M.A.; Ferreira Neto, R.A.; Silva, D.K.A.; Melo, A.L.; Oehl, F.; Maia, L.O. Diversity of arbuscular mycorrhizal fungi along an environmental gradient in the Brazilian semiarid. Applied Soil Ecology, v.84, p. 66175, 2014. https://doi.org/10.1016/j.apsoil.2014.07.008 
Souza, T.A.F. Handbook of arbuscular mycorrhizal fungi. 1.ed. Switzerland: Springer International Publishing, 2015. 153p. https://dx.doi.org/10.1007/978-3-319-24850-9

Schüßler, A.; Schwarzott, D.; Walker, C. A new fungal phylum, the Glomeromycota: phylogeny and evolution. Mycological Research, v.105, n.12, p.1413-1421, 2001. https://doi.org/10.1017/S0953756201005196

Souza, T.A.F.; Andrade, L.A.; Freitas, H.; Sandim, A.S. Biological invasion influences the outcome of plant-soil feedback in the invasive plant species from the Brazilian semi-arid. Microbial Ecology, v.76, n.1, p.102-112, 2018. https://dx.doi.org/10.1007/s00248-017-0999-6

Souza, T.A.F.; Freitas, H. Arbuscular mycorrhizal fungal Community assembly in the Brazilian tropical seasonal dry forest. Ecological Processes, v.6, n.2, p.1-10, 2017. https://dx.doi.org/10.1186/s13717-017-0072-x

Souza, T.A.F.; Rodrigues, A.F.; Marques, L.F. Long-term effects of alternative and conventional fertilization. I: effects on arbuscular mycorrhizal fungi community composition. Russian Agricultural Science, v.41, n.6, p.454-461, 2015. https://doi.org/10.3103/S1068367415060245

Souza, T.A.F.; Rodriguez-Echeverría, S.; Andrade, L.A.; Freitas, H. Arbuscular mycorrhizal fungi in Mimosa tenuiflora (Willd.) Poir from Brazilian semi-arid. Brazilian Journal of Microbiology, v.47, n.2, p.359-366, 2016b. http://dx.doi.org/10.1016/j.bjm.2016.01.023

Souza, T.A.F.; Rodruiguez-Echeverría, S.; Andrade, L.A.; Freitas, H. Could biological invasion by Cryptostegia madagascariensis alter the composition of the arbuscular mycorrhizal fungal community in semi-arid Brazil? Acta Botanica Brasilica, v.30, n.1, p.93-101， 2016a. https://dx.doi.org/10.1590/0102$33062015 \mathrm{abb} 0190$

Souza, T.A.F.; Santos, D. Effects of using different host plants and long-term fertilization systems on population sizes of infective arbuscular mycorrhizal fungi. Symbiosis, v.76, n.2, p.139-149, 2018. https://doi.org/10.1007/s13199018-0546-3

Vogelsang, K.M.; Bever, J.D. Mycorrhizal densities decline in association with nonnative plants and contribute to plant invasion. Ecology, v.90, n.2, p.399-407, 2009. https://doi.org/10.1890/07-2144.1

Walker, C.; Vestberg, M.; Demircik, F.; et al. Molecular phylogeny and new taxa in the Archaeosporales (Glomeromycota): Ambispora fennica gen. sp. nov., Ambisporaceae fam. nov., and emendation of Archaeospora and Archaeosporaceae. Mycological Research, v.111, n.2, p.137-153, 2007. https://doi.org/10.1016/j.mycres.2006.11.008

WRB, IUSS, Working Group. World reference base for soil. World Soil Resour. Rep., no 103. 2006, 145 p. http://www.fao.org/3/a-a0510e.pdf

Zhang, Q.; Yang, R.; Tang, J.; Yang, H.; Hu, S.; Chen, X. Positive feedback between mycorrhizal fungi and plants influences plant invasion success and resistance to invasion. PLoS ONE, v.5, n8, e12380, 2010. http://doi.org/10.1371/journal.pone.0012380

Zubek, S.; Majewska, M.L.; Błaszkowski, J.; Stefanowicz, A.M.; Nobis, M.; Kapusta, P. Invasive plants affect arbuscular mycorrhizal fungi abundance and species richness as well as the performance of native plants grown in invaded soils. Biology and Fertility of Soils, v.52, n.6, p.879-893, 2016. https://doi.org/10.1007/s00374-016-1127-3 